\title{
The Use of Chelates to Control Iron Chlorosis in Soybeans Grown in Alkaline Substrate Under Greenhouse Conditions
}

\author{
E. Hernández-Medina ${ }^{1}$
}

\section{INTRODUCTION}

It is often observed that iron chlorosis develops in plants grown under greenhouse conditions in sand or water cultures. This situation is frequently attributable to the precipitation of iron by phosphates when they are used in relatively high concentrations or in nutrient solutions with $\mathrm{pH}$ values above 6.

Though the maintenance of adequate iron for greenhouse plants might be a problem, it is not as serious as with plants grown under field conditions because of the complexity of the soil problems involved. Iron chlorosis is of common occurrence in the citrus-growing sections of Florida, both on the alkaline soils of the East Coast and in acid soils elsewhere $(9,10,11) .^{2}$ It is also prevalent in the northwestern States where it is induced by high soil alkalinity. In Hawaii and Puerto Rico $(3,5,6,7)$ iron chlorosis has been reported to be caused by high manganese concentration in the soil. Excessive use of soil phosphorus (2) may be a factor responsible for lack of iron in plants. Thus, it is apparent that the problem of iron-induced chlorosis is of importance in some agricultural areas.

During the past few years attention has been given to the use of the new iron compound commonly known as iron sequestrene as a feasible way of correcting iron deficiency in tree fruits and other crops. This compound is a complex form of iron made up by combining salts of ethylenediamine tetraacetic acid (EDTA) with iron, thus forming a very stable iron complex. It is believed this iron complex is rendered available to the plant without being broken down in the soil $(9,10,11)$. These organic compounds which combine with iron or any other metals are commonly called chelating agents. This paper reports on the results of tests conducted under greenhouse conditions to determine the effectiveness of a chelate compound ( $\mathrm{NaFe}$ sequestrene) in controlling iron chlorosis in soybean plants grown in an alkaline substrate.

\section{REVIEW OF LITERATURE}

The literature dealing with the use of iron sequestrene or chelated iron in experimental work is rather scant. Iron chlorosis in fruit trees has been

${ }^{1}$ Associated Horticulturist, Agricultural Experiment Station, University of Puerto Rico, Río Piedras, P. R.

${ }^{2}$ Numbers in parentheses refer to Literature Cited, p. 254. 
controlled by using chelated iron. Stewart and Leonard $(9,10,11)$ working in Florida corrected iron chlorosis in orange trees by applying chelated iron to an acid soil at the rate of 10 to $20 \mathrm{gm}$. in solution around the trees. Trees became green about 6 weeks after the organic compound was applied. Results on calcareous soils indicated that higher rates of application of the compound were required. Iron deficiency has also been controlled by using EDTA in the soil without supplementing it with iron. The authors point out that probably the iron in the soil was chelated by the added sequestrene. Chemical analyses for total iron in the leaves of the new spring growth of orange trees which received chelated iron was found to be almost twice that found in leaves from nearby untreated trees, or in leaves treated with 15 pounds of iron sulfate.

Jacobson (4) has demonstrated that the iron supply in the nutrient solution can be maintained by using ferric potassium ethylenediamine tetraacetate. He found that nutrient solutions containing 5 or 10 p.p.m. of iron provided adequate iron to such plants as tomatoes, corn, barley, and sunflower.

As mentioned by Alexander and Walsh (1), sequestrene, in combination with iron, maintains iron in solution so that a substantial amount would be available for plant assimilation in but a single application, whereas multiple applications of iron citrate would be required to achieve comparable results. The authors suggest that applications of the iron complex as a spray to the leaves of chlorotic plants is also promising in correcting iron-induced chlorosis.

Samuels and Cibes (8) obtained satisfactory control of iron chlorosis on Dracaena sanderiana, under greenhouse condition, by using Fe-EDTA sprays ( 1 pound per 100 gallons). They reported that ferrous sulfate sprays were not effective.

\section{MATERIAL AND METHODS}

\section{CULTURAL METHODS}

Seeds of soybeans, variety Lincoln, selected for uniformity in size were soaked in distilled water for about 2 hours. After this they were transferred to moist filter paper in petri dishes and incubated at a temperature of $33^{\circ} \mathrm{C}$. After germination and when the hypocotyls were about 3 to $4 \mathrm{~cm}$. in length, the germinated seeds with seedcoats removed were transferred to a paraffined cloth net stretched tightly over a pan containing a dilute nutrient solution. At the end of 10 days the best seedlings were selected and transferred to the culture jars. First, the seedlings received a complete nutrient solution of similar composition to one of the solutions used later in the experiment, but at one-half strength. Trace elements including iron 
were supplied too. At the end of about a week, differential nutrient treatments were started and maintained for 21 days.

There were 12 cultures which were divided into two groups of 6 cultures each. One group of cultures was grown in a complete nutrient solution with $\mathrm{pH}$ adjusted to 5, while the second group was grown in a nutrient solution with $\mathrm{pH}$ adjusted to 7 . The $\mathrm{pH}$ of the nutrient solutions was adjusted to the desired value by varying the concentrations of potassium sulfate and substituting the monopotassium acid phosphate by dipotassium acid phosphate where a $\mathrm{pH}$ of 7 was required. The composition of the nutrient solutions in molar concentrations, to which the plants were subjected is shown in the following tabulation:

$\begin{array}{lr}\mathrm{Ca}\left(\mathrm{NO}_{3}\right)_{2} & 0.005 \\ \mathrm{~K}_{2} \mathrm{SO}_{4} & .002 \\ \mathrm{KH}_{2} \mathrm{PO}_{4} & .001 \\ \mathrm{MgSO}_{4} & .002\end{array}$

The treatments at each $\mathrm{pH}$ level were as follows:

$\begin{array}{cc}\text { Culture } & \text { Treatment } \\ 1 & 0.5 \text { p.p.m. inorganic iron as iron sulfate } \\ 2 & .01 \text { p.p.m. iron as iron sequestrene } \\ 3 & .5 \text { p.p.m. iron as iron sequestrene }\end{array}$

Only $0.0015 \mathrm{M} \mathrm{K}_{2} \mathrm{SO}_{4}$ with $\mathrm{K}_{2} \mathrm{HPO}_{4}$, instead of the $\mathrm{KH}_{2} \mathrm{PO}_{4}$, was used in cultures requiring $\mathrm{pH} 7$, as mentioned previously. Trace elements were supplied, expressed in parts per million as follows: B $0.1, \mathrm{Mn} 0.005$ or 0.25 , Mo $0.01, \mathrm{Cu} .0 .01$, and $\mathrm{Zn} 0.002$. The ratio of iron to manganese was kept at $2: 1$.

Plants in the various treatments were harvested 3 weeks after the treatment differentials were set. The tops were sectioned from the roots and weighed. The uppermost leaves and buds of each plant were then removed and rinsed in distilled water. Then they were blotted with absorbent paper and weights were recorded. Next, the tissue was divided into two portions, one of which was immediately frozen in a deep freezer while the other portion was dried. This was necessary in order to determine the total and soluble iron and manganese content of the leaf tissue desired.

\section{ANALYTICAL METHODS}

For determining the soluble iron and manganese the frozen-tissue samples were thawed and wrapped in a piece of muslin, and then placed in an aluminum cylinder and subjected to a pressure of 2,000 pounds per square inch for three consecutive periods in a Carver press, each period of extraction amounting to 1 minute. About 5 cc. of distilled water was added to 
each sample at each period to aid in the extraction of the cell sap. The press cake obtained was weighed after drying and was used for the determination of iron and manganese. Soluble iron and manganese of the tissue were determined by the difference between the analytical values of these two elements in the unextracted sample and the extracted press cake. Thus, it is assumed here that the juices extracted by pressure contained the soluble part of iron and manganese, while those remaining in the press cake were considered to be the inactive or insoluble iron and manganese.

The procedure used by Toth et al. (12) was followed for the determination of iron and manganese in the leaf samples. Iron was determined colorimetrically as the ferrous orthophenanthroline complex. Manganese was determined colorimetrically as the permanganic acid after oxidation with periodate.

\section{RESULTS AND DISCUSSION}

EFFECT OF TREATMENT ON PLANT GROWTH

Figure 1 shows the response of the soybean plants to the different treatments. During the course of the experiment it was observed that plants which were grown in the nutrient solution maintained at $\mathrm{pH} 5$ and which received 0.5 p.p.m. iron as iron sulfate, or 0.5 p.p.m. as iron sequestrene, developed normally. No evidence of chlorosis was observed in these plants which indicated that the iron supply was sufficient for their metabolic proc-

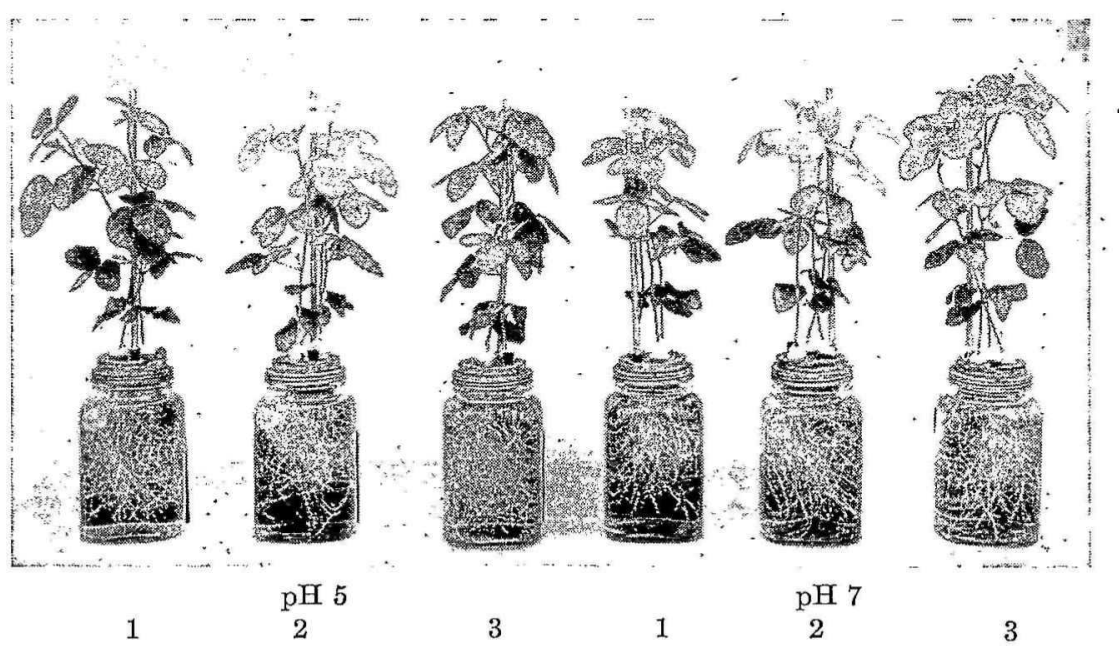

Frg. 1.-Degree of iron chlorosis in soybean plants at $\mathrm{pH} 5$ : Culture 1, 0.5 p.p.m. iron as iron sulfate; culture 2, 0.01 p.p.m. chelated iron; culture 3, 0.5 p.p.m. chelated iron. At pH 7: Culture 1, 0.5 p.p.m. iron as iron sulfate; culture 2, 0.01 p.p.m. chelated iron; culture 3, 0.5 p.p.m. chelated iron. 
esses (cultures 1,3 ). On the other hand, the plants supplied with 0.01 p.p.m. iron as iron sequestrene (culture 2) developed a chlorosis in the newly formed leaves as well as in the next youngest leaves. Leaves were yellow and somewhat crinkled with many tiny brownish spots scattered on the surface. This indicated that the iron supplied in the nutrient solution, although in the chelated form, was insufficient to supply the plants with an adequate quantity and therefore iron-induced chlorosis developed.

Observations made on the plants grown in the nutrient solution maintained at $\mathrm{pH} 7$ revealed rather interesting facts. Those plants which received 0.5 p.p.m. iron as iron sulfate had yellow tops and tiny brown spots, and had crinkled and cup-shaped leaves (culture 1). On the other hand, the plants that received 0.5 p.p.m. of iron as iron sequestrene did not show any evidence of iron chlorosis (culture 3). They were healthy and green throughout the duration of the experiment. This indicates that iron was apparently taken by the roots freely from the chelate form, and not from the iron sulfate, in sufficient quantity to satisfy the needs of the plants at this high $\mathrm{pH}$ level. Probably at $\mathrm{pH} 7$ most of the iron in the sulfate form precipitated as insoluble iron phosphate and therefore was insufficient for root absorption.

Plants which received 0.01 p.p.m. of chelated iron were quite chlorotic and had crinkled, and cup-shaped leaves with necrotic spots scattered over the leaf surface (culture 2). This last group of plants grown at pH 7, were much more chlorotic than plants grown at $\mathrm{pH} 5$ with same level of iron sequestrene.

EFFECT OF TREATMENTS ON FRESH AND DRY WEIGHT OF TOPS AND ROOTS

Table 1 presents the results obtained as to fresh and dry weights of the tops and roots of the plants, including the calculated top/root ratios.

It can be seen that plants grown in the nutrient solution maintained at pH 5 and which received 0.5 p.p.m. of iron in the chelated form (culture 3 ) surpassed the plants in other treatments in fresh and dry weights of tops as well as in fresh and dry weights of roots, but differences at this $\mathrm{pH}$ level were not significant.

When considering the results obtained from plants under the same treatments at $\mathrm{pH}$ of 7 , it is also evident that those which received 0.5 p.p.m. of chelated iron (culture 3) surpassed plants in other treatments in the various criteria considered, but were only significantly superior with respect to green and dry weight of tops. Percentage differences as high as 20 or 25 were obtained for green and dry weights of plants grown with 0.5 p.p.m. of chelated iron as compared to those receiving 0.01 p.p.m. of chelated iron or 0.5 p.p.m. of iron as iron sulfate. 
TABLE 1.-Fresh and dry weights of tops and roots of soybean plants grown under the various treatments

\begin{tabular}{|c|c|c|c|c|c|c|}
\hline $\begin{array}{l}\mathrm{pH} \text { and } \\
\text { culture No. }\end{array}$ & Treatment & $\begin{array}{l}\text { Fresh } \\
\text { weight of } \\
\text { tops }\end{array}$ & $\begin{array}{l}\text { Dry } \\
\text { weight of } \\
\text { tops }\end{array}$ & $\begin{array}{c}\text { Fresh } \\
\text { weight of } \\
\text { roots }\end{array}$ & $\begin{array}{c}\text { Dry } \\
\text { weight of } \\
\text { roots }\end{array}$ & $\begin{array}{l}\text { Ratio, } \\
\text { top/root }\end{array}$ \\
\hline & & Gm. & Gm. & Gm. & Gm. & \\
\hline pH 5: & $\begin{array}{l}0.5 \text { p.p.m. inorganic iron as } \\
\text { iron sulfate }\end{array}$ & 20.25 & 2.25 & 5.5 & 0.43 & 5.23 \\
\hline 2 & $\begin{array}{l}\text { Iron sequestrene contain- } \\
\text { ing } 0.01 \text { p.p.m. iron }\end{array}$ & 19.50 & 2.25 & 6.4 & .46 & 4.89 \\
\hline 3 & $\begin{array}{l}\text { Iron sequestrene contain- } \\
\text { ing } 0.5 \text { p.p.m. iron }\end{array}$ & 21.25 & 2.36 & 6.9 & .48 & 4.92 \\
\hline pH 7: & & & & & & \\
\hline 1 & $\begin{array}{l}0.5 \text { p.p.m. inorganic iron as } \\
\text { iron sulfate }\end{array}$ & 20.45 & 2.27 & 7.7 & .51 & 4.45 \\
\hline 2 & $\begin{array}{l}\text { Iron sequestrene contain- } \\
\text { ing } 0.01 \text { p.p.m. iron }\end{array}$ & 19.45 & 2.19 & 7.9 & .50 & 4.38 \\
\hline 3 & $\begin{array}{l}\text { Iron sequestrene contain- } \\
\text { ing } 0.5 \text { p.p.m. iron }\end{array}$ & 24.35 & 2.74 & 8.6 & .56 & 4.89 \\
\hline \multicolumn{2}{|c|}{$\begin{array}{l}\text { L.S.D. }(0.05) \text { between two culture } \\
\text { means for same } \mathrm{pH} \text { level }\end{array}$} & 3.03 & 0.42 & 1.63 & 0.14 & \\
\hline
\end{tabular}

\section{CHEMICAL ANALYSES}

The results of the chemical determinations for total and soluble iron and manganese of the upper leaves of the plants which underwent the various treatments are presented in table 2.

From the results obtained on total and soluble iron in the upper leaves of plants grown in the nutrient solution maintained at $\mathrm{pH} 5$, it seems that soluble iron is related to the total iron content of the tissue which, in turn, appears to be determined by the iron concentration of the substrate. Thus total and soluble iron were least for plants of culture 2 (0.01 p.p.m. of chelated iron in the substrate) and higher for plants of cultures 1 and 3 which contained 0.5 p.p.m. of iron, either chelated or nonchelated, in the nutrient medium.

It is of interest to note that the soluble-iron content of the upper leaves of the plants which received 0.5 p.p.m. of iron in the chelated and in the inorganic form was practically the same (cultures 1 and 3). These were the plants which did not show any sign of chlorosis when grown at pH 5 (fig. 1). Thus, at $\mathrm{pH} 5,0.5$ p.p.m. of inorganic iron as iron sulfate was as effective as 0.5 p.p.m. of chelated iron in maintaining the plants in a healthy condition. However, 0.01 p.p.m. of chelated iron was insufficient to keep plants growing normally. 
TABLE 2.-Results of chemical analyses for total as well as soluble iron and manganese of the upper leaves of soybean plants grown under the various treatments ${ }^{1}$

\begin{tabular}{|c|c|c|c|c|c|c|c|}
\hline $\begin{array}{l}\mathrm{pH} \text { and } \\
\text { culture No. }\end{array}$ & Treatment & Total Fe & $\begin{array}{l}\text { Soluble } \\
\mathrm{Fe}\end{array}$ & $\begin{array}{l}\text { Soluble } \\
\text { Fe in } \\
\text { total }\end{array}$ & Total Mn & $\begin{array}{l}\text { Soluble } \\
\text { Mn }\end{array}$ & $\begin{array}{l}\text { Soluble } \\
\text { Mn in } \\
\text { total }\end{array}$ \\
\hline & & P.p.mz. & P.p.m. & Percent & P.p.m. & P.p.m. & Percent \\
\hline 1 & $\begin{array}{l}0.5 \text { p.p.m. inorganic iron } \\
\text { as iron sulfate }\end{array}$ & 148.32 & 41.07 & 27.6 & 82.50 & 29.22 & 35.4 \\
\hline 2 & $\begin{array}{l}\text { Iron sequestrene contain- } \\
\text { ing } 0.01 \text { p.p.m. iron }\end{array}$ & 111.13 & 21.10 & 18.9 & 16.50 & 9.84 & 59.6 \\
\hline 3 & $\begin{array}{l}\text { Iron sequestrene contain- } \\
\text { ing } 0.5 \text { p.p.m. iron }\end{array}$ & 150.94 & 42.06 & 27.8 & 75.00 & 27.63 & 36.8 \\
\hline pH 7: & & & & & & & \\
\hline 1 & $\begin{array}{l}0.5 \text { p.p.m. inorganic iron } \\
\text { as iron sulfate }\end{array}$ & 121.22 & 13.93 & 10.7 & 74.25 & 20.97 & 28.2 \\
\hline 2 & $\begin{array}{l}\text { Iron sequestrene contain- } \\
\text { ing } 0.01 \text { p.p.m. iron }\end{array}$ & 98.75 & 12.99 & 14.1 & 13.20 & 6.21 & 47.0 \\
\hline 3 & $\begin{array}{l}\text { Iron sequestrene contain- } \\
\text { ing } 0.5 \text { p.p.m. iron }\end{array}$ & 162.50 & 49.72 & 30.6 & 65.00 & 25.04 & 38.5 \\
\hline \multicolumn{2}{|c|}{$\begin{array}{l}\text { L.s.D. }(0.05) \text { between } 2 \text { culture } \\
\text { means for same pH level }\end{array}$} & 2.67 & 2.19 & & 5.63 & 3.75 & \\
\hline \multicolumn{2}{|c|}{$\begin{array}{l}\text { L.S.D. }(0.01) \text { between } 2 \text { culture } \\
\text { means for same } \mathrm{pH} \text { level }\end{array}$} & 4.43 & 3.63 & & 9.33 & 6.22 & \\
\hline
\end{tabular}

${ }^{1}$ The ratio of iron to manganese in the nutrient solution at any given treatment was kept at $2: 1$

The upper leaves of plants grown in solutions at $\mathrm{pH} 7$ at the lowest concentration of iron ( 0.01 p.p.m. of chelated iron) had the lowest total and soluble-iron content. It can be seen that both the total and the soluble iron of these plants were reduced more at the higher than at the lower $\mathrm{pH}$ of the nutrient solution. The same was true for the plants which were supplied with 0.5 p.p.m. of inorganic iron as iron sulfate (culture 1). On the other hand, plants supplied with 0.5 p.p.m. of chelated iron in the nutrient solution had the highest total- and soluble-iron contents in their upper leaves. Thus, from the results obtained on iron content of the upper leaves of plants grown at $\mathrm{pH} 7$, it is evident that the two lowest soluble-iron contents were associated with iron chlorosis while highest was associated with healthy plants. Under the conditions of this experiment the use of iron sequestrene containing 0.5 p.p.m. of iron was enough to maintain soybean plants healthy at $\mathrm{pH} 7$ without any sign of chlorosis. Figure 2 illustrates graphically the soluble-iron content of the upper leaves of plants under the various treatments.

Table 2 further shows that, at either $\mathrm{pH} 5$ or 7 , the total and soluble 


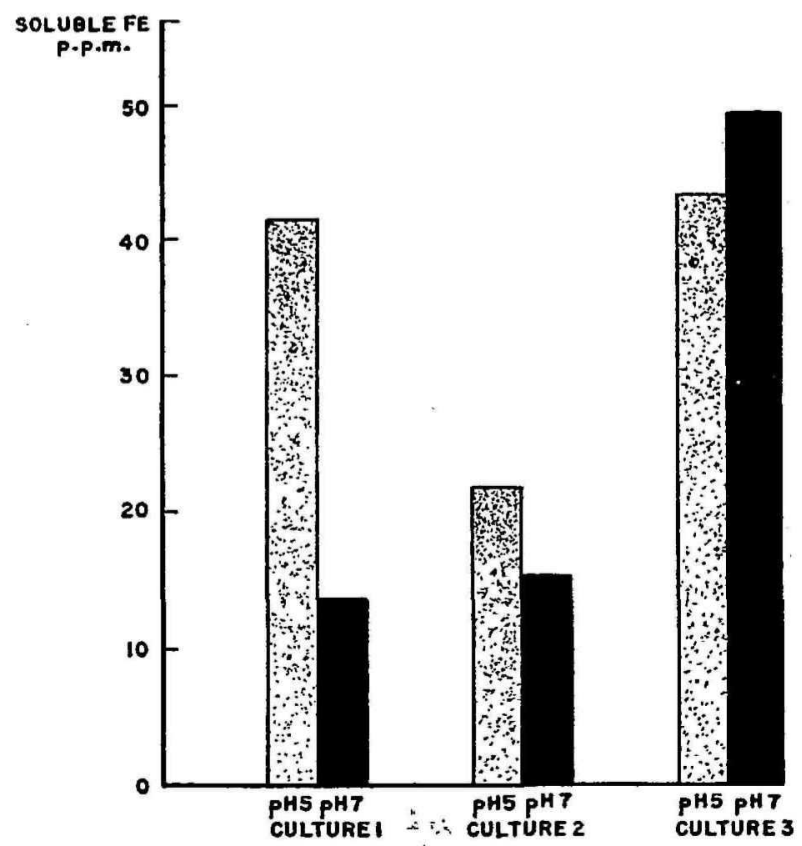

Frg. 2.-Soluble-iron content of the top leaves of soybean plants grown at two $\mathrm{pH}$ levels: Culture 1, plants grown with 0.5 p.p.m. of inorganic iron as iron sulfate; culture 2 , plants grown with 0.01 p.p.m. of iron as chelated iron; culture 3 , plants grown with 0.5 p.p.m. of iron as chelated iron.

manganese content of the leaves analyzed was dependent on the concentration of this element in the nutrient solution. Manganese absorption was greatest from the nutrient solution maintained at a $\mathrm{pH}$ of 5 than from the one maintained at a $\mathrm{pH}$ of 7 .

In conclusion, inorganic iron as iron sulfate was ineffective in maintaining soybean plants devoid of chlorosis at a $\mathrm{pH}$ of 7 . The fact that only chelated iron in adequate amounts was capable of maintaining soybean plants healthy without any evidence of iron-induced chlorosis at a $\mathrm{pH}$ of 7 of the nutrient solution suggests the feasibility of using chelated iron in alkaline soils under field conditions to control iron-induced chlorosis due to high $\mathrm{pH}$ of the soil.

\section{SUMMARY}

Soybean plants, variety lincoln, were grown in solution cultures at two $\mathrm{pH}$ levels, 5 and 7 , to determine the effectiveness of iron sequestrene in maintaining iron available to the plants. The results obtained may be summarized as follows:

1. Plants grown in nutrient solution maintained at $\mathrm{pH} 5$ and receiving 
the lowest level of chelated iron ( 0.01 p.p.m. of iron) developed iron chlorosis in the upper leaves while plants grown at $\mathrm{pH} 5$, but receiving inorganic iron as iron sulfate, and chelated iron in amounts of 0.5 p.p.m., developed healthy without any sign of iron-deficiency symptoms.

2. Iron-deficièncy symptoms were characterized by a yellowing of the upper leaves followed by crinkling of these leaves and the appearance of small necrotic spots scattered on their surface. In some cases, some reddish pigmentation was noticed.

3. Fresh and dry weights of tops and roots of plants supplied with chelated iron ( 0.5 p.p.m.) were consistently higher at both $\mathrm{pH}$ levels than those of plants supplied with the lowest level of chelated, 0.01 p.p.m., or inorganic iron, 0.5 p.p.m.

4. Upper leaves of plants whether grown at $\mathrm{pH} 5$ or $\mathrm{pH} 7$, but which received 0.01 p.p.m. of chelated iron, had the lowest content of total and soluble iron. These plants were chlorotic.

5. The upper leaves of plants grown at $\mathrm{pH} 5$ and which received chelated or inorganic iron in concentration of 0.5 p.p.m. developed without any sign of iron-deficiency symptoms. However, at $\mathrm{pH} 7$, inorganic iron was ineffective in maintaining healthy plants and iron chlorosis developed. At a $\mathrm{pH}$ of 7 chelated iron was as effective as at $\mathrm{pH} 5$.

6. The total- and soluble-manganese contents of the upper leaves of plants grown in nutrient solutions maintained at a $\mathrm{pH}$ of 5 or 7 , respectively, depended on the manganese concentration of the substrate.

\section{RESUMEN}

Se sembraron plantas de habichuela soya, variedad Lincoln, en soluciones nutritivas a dos distintos niveles de $\mathrm{pH}$ ( $\mathrm{pH}$ 5, y 7) para determinar el efecto del quelato de hierro en cuanto a mantener el hierro disponible a las plantas. Los resultados obtenidos de este estudio se resumen a continuación.

1. A las plantas en la solución nutritiva con un $\mathrm{pH}$ de 5.0 y que recibieron el nivel más bajo quelato de hierro (0.01 p.p.m. de hierro) se les desarrolló una clorosis en las hojas superiores. Las plantas mantenidas en un $\mathrm{pH}$ de 5, pero que recibieron hierro inorgánico en forma de sulfato y de quelato en cantidades de 0.5 p.p.m., se desarrollaron normalmente sin manifestar síntomas algunos de deficiencia de hierro.

2. Los síntomas de deficiencia de hierro se caracterizaron por el amarillamiento y arrugamiento de las hojas superiores de la planta y por el desarrollo de pequeños puntos necróticos esparcidos en la superficie de estas hojas. En algunos casos, se notó también un leve color rojizo en las hojas.

3. El peso verde y seco de las plantas y raíces que recibieron quelato de hierro (0.5 p.p.m. de hierro) fué consistentemente superior en ambos niveles 
de $\mathrm{pH}$ que aquel de las plantas y raíces que recibieron la cantidad mínima de quelato de hierro (0.01 p.p.m.) o hierro inorgánico en cantidad de 0.5 p.p.m.

4. Las hojas superiores de las plantas que crecieron en un $\mathrm{pH}$ de 567 , y que recibieron 0.01 p.p.m. de hierro como quelato, tuvieron la cantidad más baja de hierro total y soluble. Las plantas se veían cloróticas.

5. Las hojas superiores de las plantas que crecieron en un $\mathrm{pH}$ de 5 , y que recibieron quelato de hierro o hierro inorgánico en cantidad de 0.5 p.p.m., del elemento no demostraron síntoma alguno que pudiera atribuírse a deficiencia de hierro. Sin embargo, en el pH de 7, el hierro inorgánico no logró efecto alguno en mantener las plantas en desarrollo normal, ya que éstas se pusieron cloróticas. Cuando se usó el quelato de hierro a la misma concentración (0.5 p.p.m.), las plantas se desarrollaron normalmente.

6. El el contenido de manganeso total y manganeso soluble en las hojas de las plantas desarrolladas en soluciones nutritivas con $\mathrm{pH}$ de 5 ó 7 , estuvo relacionado con la concentración del manganeso del medio nutritivo.

\section{LITERATURE CITED}

1. Alexander, C. C., and Walsh, D. J., New chemical agent makes possible complete control of iron chlorosis, Agr. Chem. 7 (7) 36-8, 1952.

2. Chapman, H. D., Liebig, G. F., Jr., and Vanselow, A. P., Some nutritional relationships as revealed by a study of mineral deficiency and excess symptoms on citrus, Proc. Soil Sci. Soc. Amer. 4 196-200, 1939.

3. Hopkins, E. F., Pagan, V., and Ramírez-Silva, F. J., Iron and manganese in relation to plant growth, and its importance in Puerto Rico, J. Agr. Univ. of P. R. 28 43-101, 1944.

4. Jacobson, L., Maintenance of iron supply in nutrient solutions by a single addition of ferric potassium ethylenediamine tetraacetate, Plant Physiol. 26 411-3, 1951.

5. Johnson, M. O., The spraying of yellow pineapple plants on manganese soils with iron sulfate solutions, Hawaii Agr. Exp. Sta. Bul. 51, 1916.

6. - Manganese chlorosis of pineapples: Its cause and control, Hawaii Agr. Exp. Sta. Bul. 52, 1924.

7. Kelley, W. P., The influence of manganese on the growth of pineapples, Hawaii Agr. Exp. Sta. Bul. 23, 1908.

8. Samuels, G., and Cibes, H. R., Iron chlorosis on Dracaena sanderiana, J. Agr. Univ. P. R. 37 (4) 265-72, 1953.

9. Stewart, I., and Leonard, C. D., Chelates as sources of iron for plants growing in the field, Sci. 116 564-6, 1952.

10. - - Iron chlorosis: Its possible causes and control, Citrus Mag. 14 (10) 22, 1952.

11. - Possible causes and control of iron chlorosis, Calif. Citrograph 37 (11) 427, 1952.

12. Toth, S. J., et al., Rapid quantitative determination of eight mineral elements in plant tissue by a systematic procedure involving use of a flame photometer, Soil Sci. 66 (6) 459-66, 1948. 